\title{
利用机器学习方法重建末次冰盛期以来青藏高原 植被变化
}

秦锋 $^{1^{*}}$, 赵艳 ${ }^{1,3}$, 曹现勇 ${ }^{2}$

1. 中国科学院地理科学与资源研究所陆地表层格局与模拟院重点实验室, 北京 100101;

2. 中国科学院青藏高原研究所, 青藏高原地球系统与资源环境国家重点实验室, 古生态与人类适应团队, 北京 100101;

3. 中国科学院大学, 北京 100049

* 通讯作者, E-mail: qinfeng@igsnrr.ac.cn

收稿日期: 2021-05-07; 收修改稿日期: 2021-10-29; 接受日期: 2021-11-11; 网络版发表日期: 2021-12-23

国家自然科学基金项目(批准号：41690113)、中国科学院战略性先导科技专项项目(编号：XDA20070101)和国家自然科学基金项目(批准号: 42071114、41977395、41671202)资助

\begin{abstract}
摘要 地质历史时期青藏高原的植被变化为理解高寒植被响应气候变化的机制提供重要证据. 然而, 由于缺少合 适的利用孢粉化石等代用指标定量重建高寒植被的方法, 阻碍了对青藏高原过去植被变化的深入理解. 本研究基 于青藏高原及其周边地区的现代狍粉数据, 采用一种有监督机器学习方法——随机森林算法, 构建利用孢粉数据 重建青藏高原植被的模型, 对比模型对现代样点的预测结果与样点实际植被及生物群区化法的重建结果, 评估随 机森林算法建立孢粉-植被模型的可靠性. 结果显示, 基于现代孢粉数据, 利用随机森林模型重建的现代样点植被 与实际植被有较高的一致性. 与生物群区化法相比, 随机森林算法重建青藏高原地区现代植被的准确性更高, 可 能更适用于该地区的古植被重建. 基于 51 条孢粉化石记录，利用随机森林模型重建了青藏高原2.2万年以来的植 被变化, 重建的古植被格局变化大体与同时期全球气候变化和东亚季风演化趋势一致. 末次冰盛期时, 青藏高原 大部分地区是荒漠植被, 亚热带森林分布于高原东南缘. 高寒草原从未次冰消期开始扩张, 并且在高原中部和东 部逐渐形成地带性植被。高寒草甸从早全新世开始占据高原东部和东南部, 高原开始形成从东南至西北分布森 林-草甸-草原-荒漠的格局。中全新世时, 亚热带森林向北扩张, 反映最适宜期的植被状况. 之后, 高寒草甸和高寒 草原在晚全新世再次向南扩张.
\end{abstract}

关键词植被重建, 随机森林算法, 生物群区化法, 孢粉, 未次冰盛期, 青藏高原

\section{1 引言}

青藏高原的抬升影响了东亚季风强度 $(\mathrm{An}$ 等, 2001, 2015; Molnar等, 2010), 并在高原上形成了独特
的高寒生态系统(张新时, 1978; 郑度等, 1979; 吴征镒, 1980). 地质历史时期气候变化对青藏高原高寒植被形 成和发展的影响受到广泛的关注(如唐领余和李春海, 2001; Chen等, 2020; Zhao等, 2020). 末次冰盛期以来的 
植被动态反映植被对冰期向间冰期转换过程中气候变 化的响应, 青藏高原不少化石点已基于孢粉化石开展 了末次冰盛期至今的植被演变研究(如Shen等, 2006; Zhao等, 2011; Herzschuh等, 2014; Li等, 2019; Shi等, 2020).

少数综述性研究定性地描述了末次冰盛期以来青 藏高原植被分布变化的大体趋势, 如唐领余和李春海 (2001)整合青藏高原狍粉记录, 分析高原不同区域全 新世植被的变化特征; 唐领余等(2021)基于已发表的 孢粉序列, 研究了 2 万年以来青藏高原从东南到西北 不同样点的植被演替过程.

尽管青藏高原不少样点已开展了化石孢粉分析, 但基于化石狍粉组合定量重建古植被变化的研究较 少, 仅有的定量化古植被重建几乎都采用生物群区化 法(biomisation, Prentice等, 1996). Herzschuh等(2006) 报道了兹格塘错钻孔的狍粉组合, 并按照符合当地植 被特征的生物群区划分方案, 定量重建当地全新世以 来温性草原和高寒草原的变化. Herzschuh等(2009)重 建了晚冰期以来寇察湖周围苔原和草原植被的变化. Dallmeyer等(2011)重建了过去6000年青藏高原不同植 被带4个湖泊周围森林、灌丛、草原/草甸、荒漠的变 化. 上述古植被定量重建的方法相同, 但是采用了不同 的生物群区划分方案, 各研究的重建结果之间无法直 接对比.

一些基于孢粉化石数据利用生物群区化法(Prentice等, 1996)定量重建中国过去植被分布的研究中, 也涵盖青藏高原地区(Yu等, 2000; Ni等, 2014; Sun等, 2020). 不过, 这些研究聚焦于整个中国的植被分布格 局, 对青藏高原地区过去的植被变化缺乏深入分析. $\mathrm{Yu}$ 等(2000)重建了 18和6ka BP两个时段的植被分布, 使用的生物群区划分方案中能反映高寒植被的仅有苔 原(tundra)一种生物群区类型. Ni等(2014)重建了末次 冰盛期以来中国的植被分布变化, 他们采用的生物群 区划分方案中有多个苔原类型可以反映高寒植被, 但 是这些苔原类型不能完全对应青藏高原的植被. Sun 等(2020)重建了中国中全新世的植被分布, 生物群区 划分中将青藏高原的植被分为两种高寒生物群区. 总 之, 目前尚缺乏能够较全面地反映青藏高原植被状况 的定量重建方法.

另有两项研究用模型模拟的方法重建青藏高原过 去的古植被分布. Song等(2005)用生物地理-生物地球
化学模型BIOME4模拟全新世早期青藏高原的植被分 布, 与基于化石狍粉数据定性描绘的同时期青藏高原 植被分区图对比，验证模拟结果的可靠性. Dallmeyer 等(2011)用耦合大气-海洋 - 植被模型ECHAM5/ JSBACH-MPIOM模拟青藏高原6000年来的植被变化, 并用生物群区化法重建不同植被带4个样点的古植被 演变, 用以验证模拟结果. 两项研究中用于验证模拟可 靠性的代用指标证据都略显不足, 前者采用较粗尺度 上定性分析的植被分布, 而后者用少数样点的定量重 建结果表征整个高原的植被状况. 利用合适的方法, 基于化石孢粉数据全面重建青藏高原古植被变化, 将 为模型模拟与代用指标对比, 及深入探讨古植被变化 的机制提供重要证据.

最近, 一种有监督机器学习方法(supervised machine learning method)——随机森林算法(random forest algorithm)被用于建立狍粉-植被重建模型, 并定量 重建古植被变化. Sobol和Finkelstein(2018)利用非洲和 阿拉伯半岛的现代狍粉数据, 检验了包括随机森林算 法在内 8 种方法基于孢粉数据重建植被的可靠性, 结 果显示随机森林算法的准确性最高. 随后, Sobol等 (2019)利用随机森林算法在南非建立具有高准确性的 孢粉-植被重建模型, 并用该模型重建Wonderkrater地 区过去 $60 \mathrm{ka}$ 的植被变化.

机器学习方法有潜力用于青藏高原地区的古植被 定量重建, 不过其可靠性尚待验证. 本研究尝试用随机 森林算法定量重建青藏高原的古植被变化. 首先, 基于 青藏高原及其周边地区的现代狍粉数据用随机森林算 法建立孢粉-植被模型, 将新建立的模型用于现代孢粉 数据, 重建的现代植被与样点实际植被对比; 同时与生 物群区化法基于同一套现代狍粉数据的重建结果对 比, 检验随机森林模型的可靠性. 然后, 将新建立的随 机森林模型用于青藏高原 51条狍粉化石序列, 重建末 次冰盛期以来青藏高原植被的时空格局变化.

\section{2 材料与方法}

\section{1 研究区概况}

青藏高原面积约254万平方千米(张镱锂等, 2014), 高原主体海拔在 $4000 \mathrm{~m}$ 以上. 气候主要受控于印度夏 季风、东亚夏季风及中纬度西风(Chen等, 2020). 从东 南向西北沿温度和湿度梯度, 植被依次出现森林-草 
甸-草原-荒漠的高原地带性分布(张新时, 1978; 郑度 等, 1979; 张新时, 2007).

热带雨林主要分布于喜马拉雅山脉南坡低海拔地 区, 主要由热带常绿、半常绿乔木占优势, 如Dipterocarpus spp.、Artocarpus chaplasha、Dysoxylum spp.、 Canarium resiniferum、Tetrameles nudiflora、Altingia excelsa、Chukrasia tabularis、Shorea assamica等. 青 藏高原东南部分布亚热带常绿阔叶林, 优势类群主要 是壳斗科的常绿乔木, 如Castanopsis spp.、Lithocarpus spp.、Cyclobalanopsis spp.QQuercus中的常绿种 (Q. aquifolioides、Q. rehderiana、Q. semicarpifolia) 等, Schima、Machilus、Manglietia、Ficus等属的常绿 类群也常成为优势种. 此外, Pinus densata、P. yunnanesis、Tsuga dumosa 等针叶树在也占较大比例. 高原东 南部高海拔山地有大量山地寒温性针叶林, 优势类群 包括Picea(P. likiangensis、P. asperata, P. aurantiaca、 $P$. purpurea、 $P$. brachytyla var. complanata)、 Abies(A. georgei、A. squamata)、Sabina(S. tibetica、 S. saltuaria)、Pinus(P. griffithii)、Larix (L. chinensis)等 (张新时, 2007).

青藏高原东部以高寒灌从和高寒草甸植被有主. 高寒灌丛优势类群包括Rododendron(Rh. Capitatum、 Rh. Thimifolium、Rh. Przewalskii、Rh. Violaceum、 Rh. Litangensis、Rh. Nivale、Rh. Cephalanthoides、 Rh. fastigiatum)、Salix(S. cupularis、S. oriterpha、S. atopantha、S. sclerophylla)、Potentilla fruticosa、Rosa sericea、Sibiraea angustata、Spiraea alpina、Caraga$n a$ jubata等灌木. 高寒草甸优势植物主要是莎草科Kobresia(K. pygmaea、K. humilis、K. setchwanensis、K. capillifolia、K. prattii)和Carex(C. lanceolata、C. muliensis、C. meyeriana), 以及禾本科Elymus nutans、 Roegneria nutans、Stipa purpurea、S. aliena、 Deschampsia caespitosa等. 高寒草甸常见丰富的杂类 草, 如Polygonum、Potentilla、Anaphalis、Leontopodium、Taraxacum、Saussurea、Pedicularis、Anemone、Trollius、Ranunculus、Thalictrum、Gentiana、Swertia、Oxytropis、Astragalus 等属(张新时, 2007).

青藏高原中部高寒草原和温性草原占优势, 建群 种主要是Stipa(S. purpurea、S. bungeana、S. subsessiliflora var. basiplumosa、S. roborowskyii、S. capilla-
cea)、Artemisia(A. wellbyi、A. younghusbandii, A. stracheyi)、Carex(C. moorcroftii、C. montis-everestii). 其他重要类群包括Littledalea racemose、Orinus thoroldii、Pennisetum flaccidum、Aristida adscensionis等 草本植物, 以及Caragana versicolor、Sophora moorcroftiana、Sabina pingii var. wilsonii、 Potentilla fruti$\cos a$ 等灌木(张新时, 2007).

青藏高原西部和北部主要分布高寒荒漠和温性荒 漠. 优势类群主要是㢣科植物, 如Ceratoides (C. compacta、C. latens)、Salsola(S. abrotanoides)、Haloxylon(H. ammodendron)、Kalidium(K. foliatum、 $K$. cuspidatum), 喜旱植物Ephedra(E. przewalskii、E. intermedia)、Zygophyllum xanthoxylon、Nitraria(N. roborowskii、 N. sibirica)、Ajania tibetica、Artemisia(A. rhodantha、A. arenaria) 等也能在群落中占重要地位. 禾本科Stipa purpurea、S. glareosa和莎草科Carex moorcroftii 与上述典型荒漠植物可共同组成荒漠草原 (张新时, 2007).

\section{2 现代孢粉数据}

整合青藏高原及其周边 17 个植被地带 1802 个样点 的现代孢粉数据作为训练集(Cao等, 2014; Zheng等, 2014; Zhao等, 2021)(图1). 为了尽量涵盖化石记录中 可能出现的植被类型, 现代狍粉样点的覆盖范围比青 藏高原范围更广. 现代狍粉组合来自 832 个表土、 619 个苔藓及 351 个湖泊表层沉积物样品. 虽然不同沉积 物中狍粉组合特征可能存在差异(Fall, 1992; Wilmshurt和McGlone, 2005; Zhao等, 2009; Lisitsyna等, 2012), 但研究区单一沉积物类型的现代狍粉组合所能 覆盖的植被带均较为有限(图1), 所以本文采用不同沉 积物类型的现代狍粉数据作为训练集. 现代狍粉数据 集中含 504 个原始狍粉类群, 通过合并异名, 并将低等 级分类单元归并为较高等级的类群, 整理为 230 个孢粉 类群; 并重新基于陆生花粉总数计算各狍粉类群的百 分含量.

现代狍粉数据集中不少样品缺乏原始的植被描 述, 不同样点原始植被信息的获取方法可能存在差异, 如野外植被调查范围不同, 采用的植被分类方案不同 等. 因此, 所有现代狍粉样点重新根据植被图提取植 被信息, 按照样点所处植被地带划分其植被类型. 植 被地带是中国植被区划中植被区域的下级区划单位 


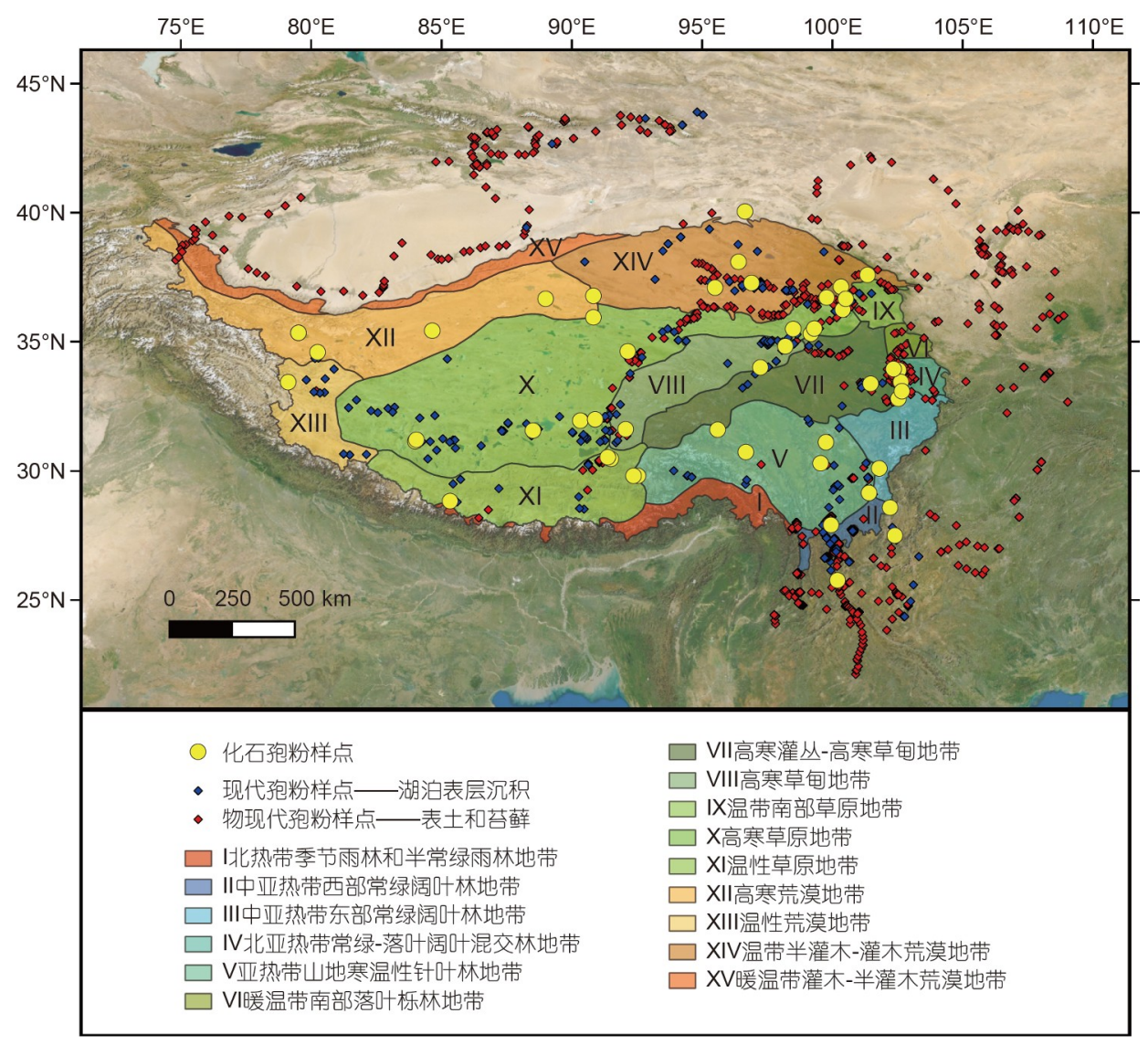

图 1 青藏高原植被区划与化石、现代狍粉样点位置

(张新时, 2007). 孢粉与植被关系研究表明，相较于识 别细尺度的植物群落信息, 现代狍粉组合能更好地区 分较粗尺度的植被带(Felde等，2014；秦锋，2021)。因 此, 在植被地带这一尺度上应能较好地反映狍粉-植被 关系, 并建立狍粉-植被重建模型.

\section{3 化石孢粉数据}

从“东亚晚第四纪狍粉数据库”(Cao等，2013)中选 取51条青藏高原化石狍粉记录(图1; 网络版附录A中 附表A1, http://earthcn.scichina.com)重建末次冰盛期以 来的植被变化. 化石点海拔在1974 5325m asl. 12个样 点位于现代亚热带森林区域, 其中4个在中亚热带常绿 阔叶林地带, 8 个在亚热带山地寒温性针叶林地带; 7 个 样点位于青藏高原的高寒灌丛-高寒草甸地带，3个位 于高寒草甸地带; 总计 15 个样点位于草原植被中, 高 寒草原地带 11 个、温性草原地带3个、温带南部草原 地带 1 个; 其余 14 个样点位于荒漠区, 包括 5 个高寒荒漠
地带、1个温性荒漠地带、8个温带半灌木-灌木荒漠 地带. 化石孢粉数据合计 269 个孢粉类群, 按照与现代 孢粉数据集相同的处理方法合并为 135 个类群.

所选化石孢粉序列的测年点位大多在 3 个以上. 采 用贝叶斯方法(Bayesian method, Blaauw和Christen, 2011)为化石孢粉序列建立新的年代-深度模型，运算 在R v. 3.5.1(R Core Team, 2018)中利用rbacon 2.3.7 (Blaauw和Christen，2019)完成. 冬给措那、木格措、 塔若错、西门错、伍须海的原始年代已使用贝叶斯方 法校正, 而敦德冰芯的年代通过年纹层确定, 这些样点 保留原始的年代-深度模型. 36 个化石孢粉序列的时间 分辨率在 500 年/样，12个在500 1000年/样，3个超过 1000年/样(附表A1). 所有化石孢粉序列均用线性插值 获取 500 年间隔的数据, $22 \mathrm{ka} \mathrm{BP}$ 至今共分为 45 个时段. 一些化石孢粉序列测年点位较少、或样品分辨率较低 (附表A1), 导致这些序列的年代可能有较大误差, 不过 本文仍将这些化石孢粉数据用于古植被重建, 以增加 
对青藏高原的空间代表性. 另外, 本研究用多样点重建 结果, 在较大尺度上研究植被格局变化,一定程度上减 少单个化石孢粉序列年代误差的影响.

\section{4 植被重建方法}

\subsection{1 随机森林算法}

基于现代孢粉组合及其相应植被信息，利用随机 森林算法(Breiman, 2001)建立狍粉-植被重建模型。该 算法基于一套数据拟合出多个分类树，并汇总所有分 类树的结果作最终预测(Breiman，2001；Cutler等， 2007). 每一个分类树都基于原始数据集的一个自助法 取样子集用分类回归树CART(classification and regression tree, Breiman等, 1984)方法拟合. 分类树的每个节 点上根据随机选取的一组预测变量中最佳预测变量进 行分割, 建成一个不需修剪的分类树. 然后, 利用未选 入自助法取样子集的袋外数据(out-of-bag, OOB, 大约 占原始数据集的 $1 / 3$ )检验该分类树, 估算误差. 所有分 类树的误差取平均值作为模型的误差(袋外误差), 用 于评估模型的预测能力. 模型建立过程中还可以通过 计算准确率平均降低程度(mean decrease in accuracy) 评价特定预测变量(本文为孢粉类群)的重要性. 通过 对袋外数据中某一变量的值做随机的序列改变，并保 持其他变量不变，用分类树对改变后的袋外数据做预 测. 此时，袋外误差相对于未修改变量时的增加程度 即可用于衡量该变量的重要性. 模型训练流程参考Sobol和Finkelstein(2018)、Sobol等(2019)的方案. 随机森 林中分类树的数量设为 500 , 每个节点随机选作预测变 量的孢粉类群数设为 11 , 样品量高于 15 的植被类型用 于模型拟合. 参数设定相同的条件下, 算法重复 100 次, 袋外误差最低的模型用于后续化石孢粉数据的预测, 定量重建青藏高原各化石点的植被变化，进而恢复末 次冰盛期以来不同时段青藏高原的植被分布格局. 随 机森林模型的建立和应用在R v.3.5.1(R Core Team, 2018)环境下利用 randomForest 4.6-14包(Liaw和Wiener, 2002)完成.

\subsection{2 生物群区化法}

基于同一套现代孢粉数据用生物群区化法(biomisation method, Prentice等, 1996)重建现代植被, 以此与 随机森林算法的预测结果对比. 该方法重建植被的步 骤如下(Prentice等，1996; Prentice和Webb III，1998):
(1) 建立植物功能型(plant function types, PFT)分类系 统，根据狍粉类群母体植物的生理生态学和生物气候 学特征, 将各孢粉类群划归一个或多个植物功能型; (2) 建立生物群区(biome)分类系统, 用特征植物功能 型定义生物群区; (3) 在前两步基础上, 建立生物群区 对狍粉类群的矩阵，表明不同生物群区中各包含哪些 孢粉类群；(4) 基于狍粉百分含量数据, 利用下列公式 计算各生物群区的相似性得分:

$$
A_{i k}=\sum_{j} \delta_{i j} \sqrt{\left\{\max \left[0,\left(p_{j k}-\theta_{j}\right)\right]\right\}},
$$

式中, $A_{i k}$ 是孢粉样品 $k$ 中生物群区 $i$ 的相似性得分; $\delta_{i j}$ 为 生物群区 $\times$ 孢粉类群矩阵中孢粉类群 $j$ 是否出现于生物 群区 $i$ 中; $p_{j k}$ 是狍粉样品 $k$ 中类群 $\mathrm{j}$ 的百分含量; $\theta_{j}$ 为狍粉 百分含量阈值，本文采用 $0.5 \%$. 计算出相似性得分后， 孢粉样品的植被类型指定为相似性得分最高的生物群 区. 多个生物群区的相似性得分相同时, 以包含特征植 物功能型最少的生物群区作为该样品的生物群区类型 (Prentice等，1996). 植物功能型和生物群区划分采用 Sun等(2020)的分类方案, 详见网络版附录B的附表 B1 B3. 该方案包含二个对应青藏高原高寒植被的生 物群区类型，并且用现代狍粉数据重建中国现代植被 分布时显示出较高的准确性(Sun等, 2020). 生物群区 化法的运算用3Pbase软件(Guiot和Goeury, 1996)进行.

\section{3 结果}

\section{1 随机森林算法结果}

基于13个植被地带共 1764 个现代狍粉组合(每个 植被地带至少含 15 个样点)利用随机森林算法建立狍 粉-植被重建模型. 模型中的植被类型包括: 北热带季 节雨林和半常绿雨林、南亚热带季风常绿阔叶林、中 亚热带常绿阔叶林、北亚热带常绿-落叶阔叶混交 林、暖温带南部落叶栋林、亚热带山地寒温性针叶 林、高寒灌从一高寒草甸、高寒草甸、温带南部草 原、高寒草原、温性草原、暖温带灌木-半灌木荒 漠、温带半灌木-灌木荒漠.

随机森林模型的总袋外误差(OOB error rate)为 $23.47 \%$ ，该模型重建的现代狍粉样点的植被类型分布 与研究区植被带分布大体一致(图2)，不过模型对各植 被类型的预测准确率存在差异(表1). 


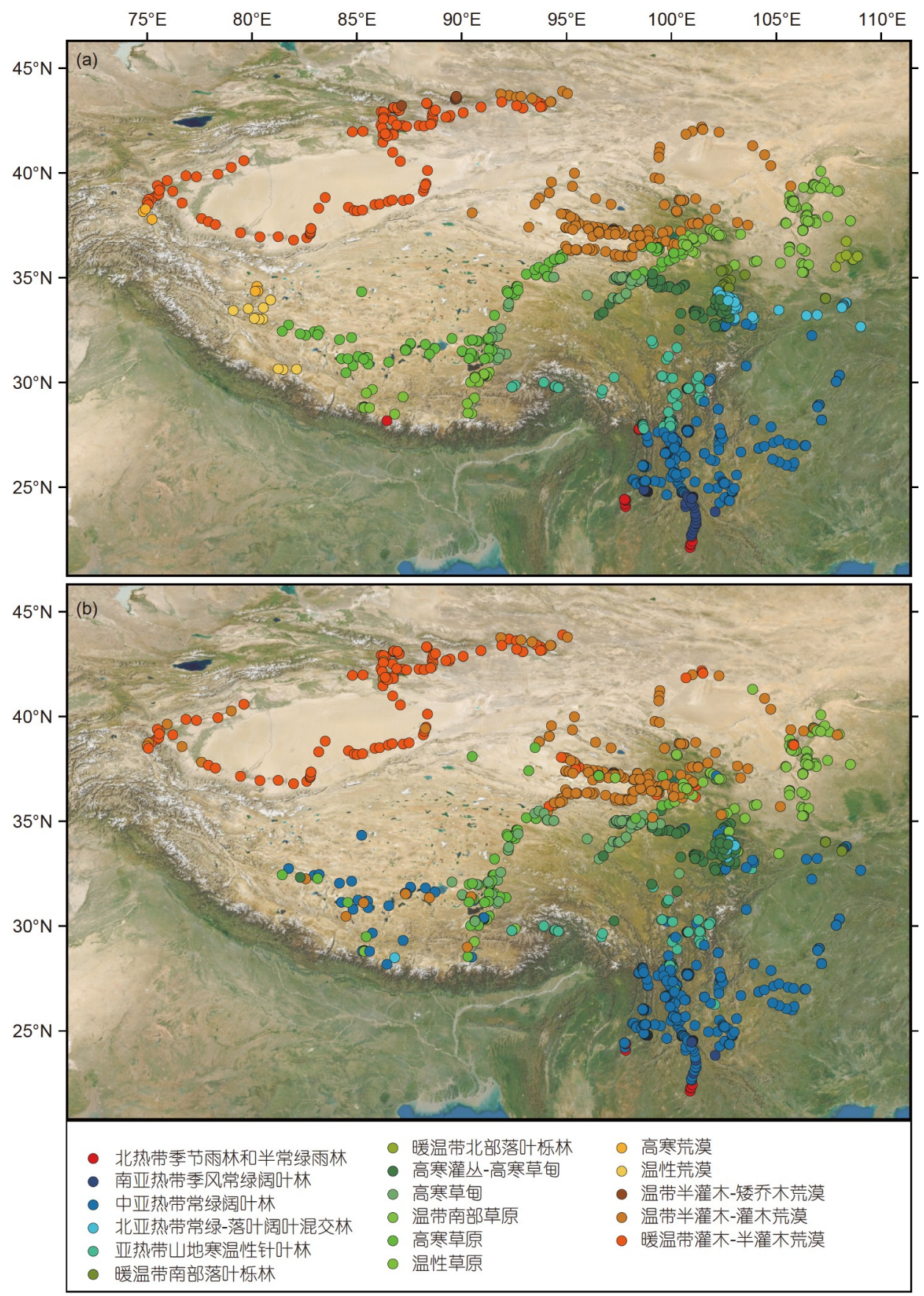

图 2 现代狍粉样点的实际植被(a)与随机森林模型重建植被(b)对比

随机森林模型对中亚热带常绿阔叶林的预测准确 率最高 $(93.56 \%)$, 该植被类型的少数样品被误判为高 寒草原 $(2.99 \%)$ 和亚热带山地寒温性针叶林 $(1.95 \%)$. 亚热带山地寒温性针叶林地带的样品大多预测准确 (72.94\%)，不过 $23.53 \%$ 该植被带的狍粉样点被判定为
中亚热带常绿阔叶林.

随机森林模型对其余森林样点的预测准确率较 低. 北热带季节雨林和半常绿雨林样品中仅 $39.29 \%$ 重 建准确, 剩余样品主要误判为中亚热带常绿阔叶林 (57.14\%). 南亚热带季风常绿阔叶林样品中仅 $29.69 \%$ 
表 1 随机森林模型对现代狍粉样品的重建结果与样点实际植被的对比 ${ }^{\text {a) }}$

\begin{tabular}{|c|c|c|c|c|c|c|c|c|c|c|c|c|c|c|}
\hline $\begin{array}{l}\text { 实际植被对 } \\
\text { 比预测结果 }\end{array}$ & NTRF & SStBEF & MStBEF & NStBEDF & StMNF & SWTDQF & $\mathrm{SaScM}$ & $\mathrm{AM}$ & STS & TS & AS & WTD & $\mathrm{TD}$ & 准确率 \\
\hline NTRF & 11 & 1 & 16 & 0 & 0 & 0 & 0 & 0 & 0 & 0 & 0 & 0 & 0 & 0.39 \\
\hline SStBEF & 0 & 19 & 44 & 0 & 1 & 0 & 0 & 0 & 0 & 0 & 0 & 0 & 0 & 0.30 \\
\hline MStBEF & 0 & 2 & 625 & 1 & 13 & 0 & 4 & 0 & 0 & 3 & 20 & 0 & 0 & 0.94 \\
\hline NStBEDF & 0 & 0 & 15 & 10 & 1 & 3 & 20 & 0 & 2 & 0 & 0 & 0 & 1 & 0.19 \\
\hline StMNF & 0 & 1 & 40 & 0 & 124 & 0 & 4 & 0 & 1 & 0 & 0 & 0 & 0 & 0.73 \\
\hline SWTDQF & 0 & 0 & 5 & 6 & 0 & 2 & 5 & 0 & 4 & 0 & 1 & 0 & 1 & 0.08 \\
\hline SaScM & 0 & 0 & 1 & 6 & 0 & 0 & 74 & 7 & 1 & 0 & 2 & 0 & 1 & 0.80 \\
\hline $\mathrm{AM}$ & 0 & 0 & 0 & 0 & 0 & 0 & 2 & 59 & 1 & 0 & 7 & 0 & 2 & 0.83 \\
\hline STS & 0 & 0 & 1 & 0 & 0 & 0 & 1 & 1 & 99 & 0 & 3 & 4 & 11 & 0.82 \\
\hline TS & 0 & 0 & 7 & 1 & 0 & 0 & 1 & 1 & 5 & 6 & 13 & 0 & 2 & 0.17 \\
\hline AS & 0 & 0 & 20 & 0 & 0 & 0 & 4 & 17 & 4 & 0 & 42 & 2 & 35 & 0.34 \\
\hline WTD & 0 & 0 & 0 & 0 & 0 & 0 & 0 & 0 & 0 & 0 & 0 & 118 & 13 & 0.90 \\
\hline TD & 0 & 0 & 0 & 0 & 0 & 0 & 1 & 0 & 6 & 0 & 5 & 11 & 161 & 0.87 \\
\hline
\end{tabular}

a) NTRF, 北热带季节雨林和半常绿雨林; SStBEF, 南亚热带季风常绿阔叶林; MStBEF, 中亚热带常绿阔叶林; NStBEDF, 北亚热带常绿落叶阔叶混交林; StMNF, 亚热带山地寒温性针叶林; SWTDQF, 暖温带南部落叶栋林; SaScM, 高寒灌从-高寒草甸; AM, 高寒草甸; STS, 温带 南部草原; TS, 温性草原; AS, 高寒草原; WTD, 暖温带灌木-半灌木荒漠; TD, 温带半灌木-灌木荒漠

预测准确，而其余大部分 $(68.75 \%)$ 同样误判为中亚热 带常绿阔叶林. 北亚热带常绿-落叶阔叶混交林样品大 多被重建为其他植被, $38.46 \%$ 重建为高寒灌从-高寒草 甸，28.85\%为中亚热带常绿阔叶林，仅 $19.23 \%$ 准确重 建为北亚热带常绿-落叶阔叶混交林. 暖温带南部落叶 栋林样品的预测准确率仅为 $8.33 \%$, 其余多被误判为 北亚热带常绿-落叶阔叶混交林 $(25.00 \%)$ 、中亚热带 常绿阔叶林(20.83\%)、高寒灌从-高寒草甸(20.83\%)、 温带南部草原(16.67\%).

随机森林模型对荒漠样品的预测准确率较高, $90.08 \%$ 的暖温带灌木-半灌木荒漠和 $87.50 \%$ 的温带半 灌木-灌木荒漠样点均能准确重建为相应植被，而误判 也多划分为另一荒漠类型.

高寒草甸样品中 $83.10 \%$ 能准确重建，其余主要误 判为高寒草原 $(9.86 \%)$. 高寒灌从-高寒草甸样品也有 $80.43 \%$ 的准确率，其余 $7.61 \%$ 被误判为高寒草甸, $6.52 \%$ 误判为北亚热带常绿-落叶阔叶混交林.

温带南部草原样点也有较高的预测准确率 (82.5\%), 误判样品多被判定为温带半灌木-灌木荒漠 (9.17\%). 高寒草原样品的预测准确率较低(33.87\%), 其他多被误判为温带半灌木-灌木荒漠 $(28.23 \%)$ 、中 亚热带常绿阔叶林(16.13\%)、高寒草甸(13.71\%). 温性
草原样品中仅 $16.67 \%$ 预测准确， $36.11 \%$ 被误判为高寒 草原， $19.44 \%$ 误判为中亚热带常绿阔叶林，13.89\%误 判为温带南部草原.

孢粉类群的准确率平均降低程度 (mean decrease in accuracy)显示它们对随机森林模型准确率的贡献各 不相同(图3). Pinus、Amaranthaceae/Chenopodiaceae、 Alnus对随机森林模型准确率影响最大, 准确率平均降 低程度均在 $5 \%$ 以上. Cyperaceae、Ephdera、Quercus (Evergreen)、Artemisia、Betula、Castanopsis/Lithocarpus 等类群的准确率平均降低程度超过 $2 \%$, 对模型 也有重要贡献. 此外, Tsuga、Abies/Picea、Nitraria、 Ranunculaceae、Quercus(Deciduous)、Juglans、Asteraceae、Ericaceae等类群准确率平均降低程度在 $1 \%$ 以 上, 重要性也较高.

\section{2 生物群区化法重建现代植被}

利用生物群区化法重建青藏高原及其周边现代孢 粉样点的植被, 结果显示现代狍粉样点被划归14个生 物群区(表2, 图4, 网络版附录 C), 包括热带雨林、热 带季节雨林、南亚热带常绿阔叶林、中亚热带常绿阔 叶林、北亚热带混交林、暖温带混交林、温带混交 林、寒温带常绿针叶林、寒温带夏绿针叶林、高寒草 


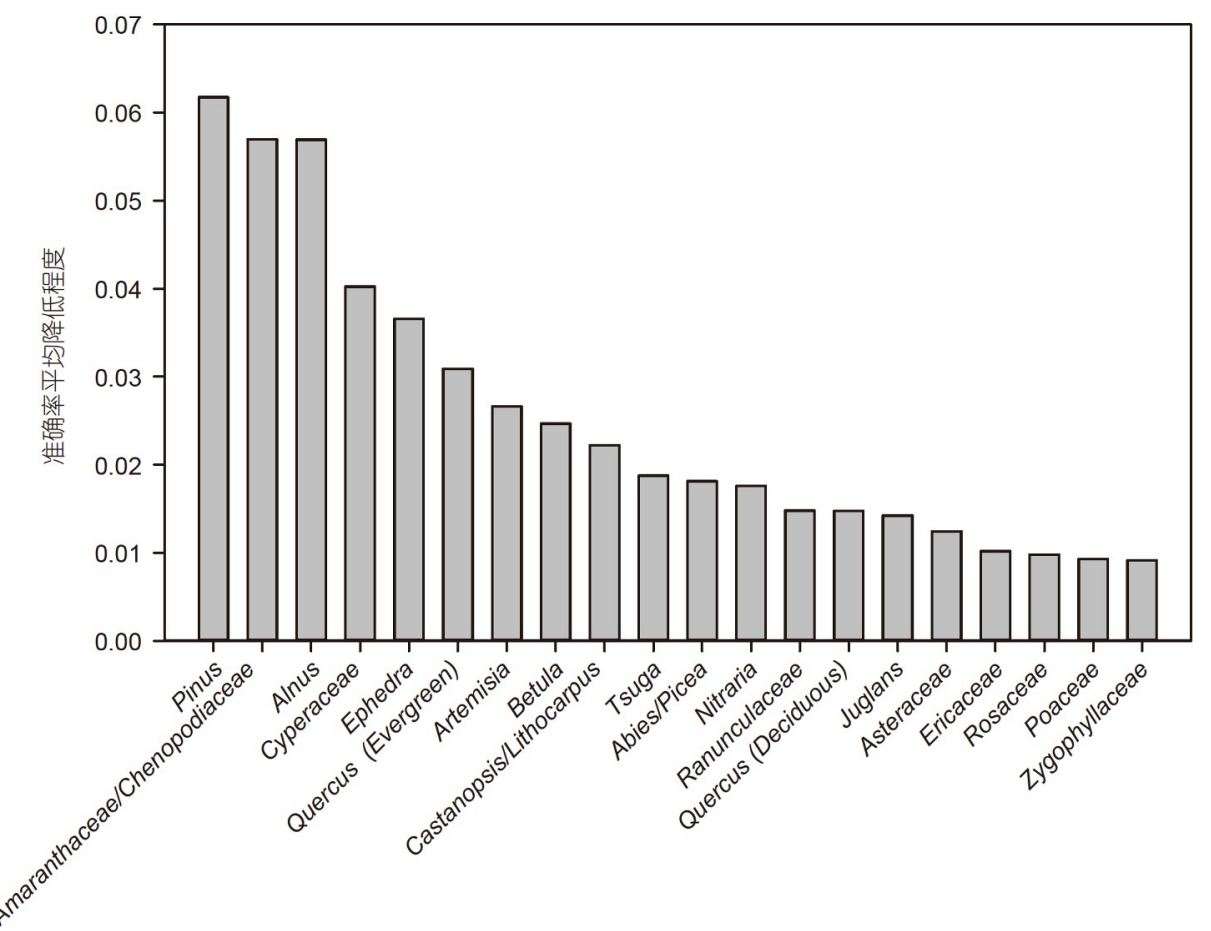

图 3 以准确率平均降低程度衡量狍粉类群在随机森林模型中的重要性

表 2 生物群区化法对现代狍粉样品的重建结果与样点实际植被的对比 ${ }^{\mathrm{a})}$

实际植被对比 TRFO TSFO STFO MTFO WAM- TEDE COM- CLEC CLDC ALME STEP TEDS ALST DESE 准确率 预测结果

\begin{tabular}{|c|c|c|c|c|c|c|c|c|c|c|c|c|c|c|c|}
\hline TRFO & 0 & 0 & 0 & 0 & 0 & 0 & 0 & 0 & 0 & 0 & 0 & 0 & 0 & 0 & 0.00 \\
\hline TSFO & 0 & 10 & 7 & 2 & 6 & 1 & 0 & 0 & 1 & 0 & 0 & 1 & 0 & 0 & 0.36 \\
\hline STFO & 0 & 0 & 0 & 1 & 5 & 2 & 4 & 49 & 3 & 0 & 0 & 0 & 0 & 0 & 0.00 \\
\hline MTFO & 6 & 13 & 15 & 13 & 222 & 45 & 48 & 292 & 1 & 6 & 4 & 2 & 1 & 0 & 0.02 \\
\hline WAMF & 0 & 0 & 0 & 1 & 1 & 3 & 12 & 7 & 0 & 10 & 4 & 0 & 13 & 1 & 0.02 \\
\hline TEDE & 0 & 0 & 0 & 0 & 0 & 2 & 7 & 3 & 0 & 4 & 6 & 0 & 1 & 1 & 0.08 \\
\hline COMX & 0 & 0 & 0 & 0 & 0 & 0 & 1 & 1 & 0 & 0 & 6 & 0 & 0 & 0 & 0.13 \\
\hline CLEC & 17 & 0 & 0 & 2 & 22 & 3 & 45 & 36 & 0 & 26 & 8 & 1 & 10 & 0 & 0.21 \\
\hline CLDC & 0 & 0 & 0 & 0 & 0 & 0 & 0 & 0 & 0 & 0 & 0 & 0 & 0 & 0 & 0.00 \\
\hline ALME & 0 & 0 & 0 & 0 & 0 & 0 & 1 & 3 & 0 & 63 & 46 & 0 & 48 & 2 & 0.39 \\
\hline STEP & 0 & 0 & 0 & 0 & 0 & 0 & 14 & 5 & 0 & 4 & 84 & 1 & 1 & 11 & 0.70 \\
\hline TEDS & 0 & 0 & 0 & 0 & 0 & 0 & 0 & 0 & 0 & 0 & 0 & 0 & 0 & 0 & 0.00 \\
\hline ALST & 0 & 0 & 0 & 0 & 0 & 0 & 0 & 26 & 0 & 6 & 71 & 8 & 25 & 24 & 0.16 \\
\hline DESE & 0 & 0 & 0 & 0 & 0 & 0 & 8 & 7 & 0 & 5 & 103 & 0 & 14 & 208 & 0.60 \\
\hline
\end{tabular}

a) TRFO, 热带雨林; TSFO, 热带季节雨林; STFO, 南亚热带常绿阔叶林; MTFO, 中亚热带常绿阔叶林; WAMF, 北亚热带混交林; TEDE, 暖温带混交林; COMX, 温带混交林; CLEC, 寒温带常绿针叶林; CLDC, 寒温带夏绿针叶林; ALME, 高寒草甸; ALST, 高寒草原; STEP, 温带草 原; TEDS, 温带荒漠草原; DESE, 荒漠 


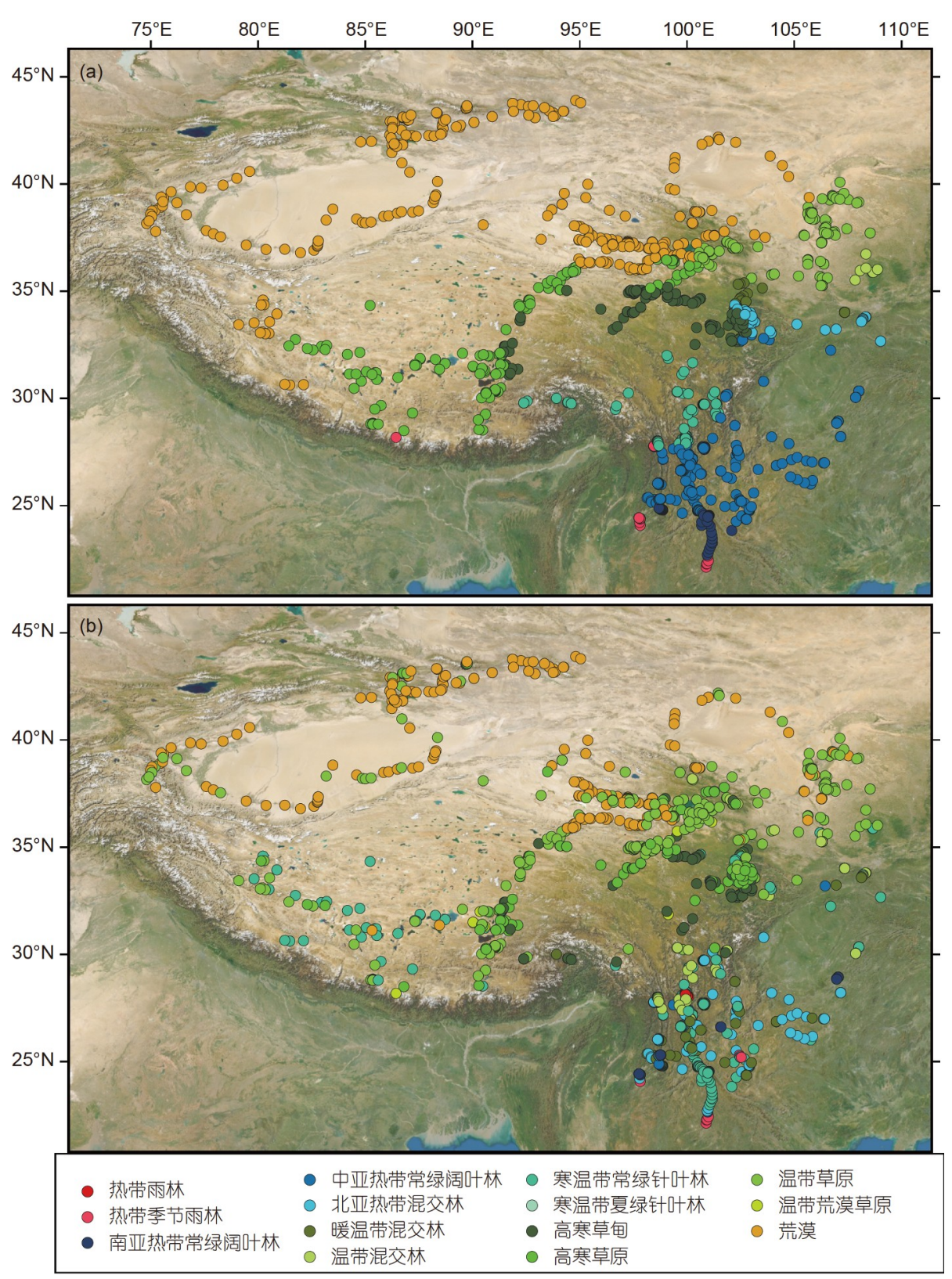

图 4 现代狍粉样点的实际生物群区(a)和用生物群区化法重建的生物群区(b)对比

甸、高寒草原、温带草原、温带荒漠草原、温带 荒漠.

利用生物群区化法重建青藏高原及其周边现代孢 粉样点植被的准确率不高(表2). 温带草原样点中重建 结果与实际植被一致的占 $70.00 \%$ ，其余 $11.67 \%$ 误判为 温带混交林, 9.17\%误判为温带荒漠. 温带荒漠样点的 重建准确率达 $60.29 \%$, 不过有 $29.86 \%$ 的样点被误判为 温带草原. 除上述两种生物群区外, 高寒草甸和热带季
节雨林的重建准确率相对较高. 高寒草甸样点中 $38.65 \%$ 预测准确, $29.45 \%$ 样点被误判为高寒草原, $28.22 \%$ 被误判为温带草原. 热带季节雨林样点中重建 植被与实际一致的占 $35.71 \%$, 其余 $25.00 \%$ 被误订为南 亚热带常绿阔叶林, $21.43 \%$ 被订为北亚热带混交林.

其他生物群区的重建准确率较低. 寒温带常绿针 叶林样点中仅 $21.18 \%$ 的重建结果与实际生物群区一 致，其余大部分被误判为温带混交林(26.47\%)、高寒 
草甸(15.29\%)、北亚热带混交林(12.94\%). 近半数的高 寒草原样点(44.38\%)被误判为温带草原，仅 $15.63 \%$ 样 点的重建结果与实际植被一致，另有不少样点被重建 为寒温带常绿针叶林 $(16.25 \%)$ 和温带荒漠(15.00\%). 温带混交林样点中仅一个样点重建准确，其余大部分 被误判为温带草原 $(75 \%)$. 暖温带混交林样点主要被 重建为暖温带混交林 $(8.33 \%) 、$ 温带混交林(29.17\%)、 温带草原 $(25.00 \%)$ 、高寒草甸(16.67\%)、寒温带常绿 针叶林 $(12.50 \%)$. 现代孢粉样点中, 中亚热带常绿润叶 林生物群区的样点数量最多, 但利用生物群区化法的 重建结果中仅有2\%重建准确，其余大部分被误订为寒 温带常绿针叶林(43.71\%)和北亚热带混交林(33.23\%). 大部分北亚热带混交林样点被重建成高寒草原 $(25.00 \%)$ 、温带混交林 $(23.08 \%)$ 、高寒草甸 $(19.23 \%)$ 、寒温带常绿针叶林 $(13.46 \%)$, 准确订为北亚 热带混交林的仅占 $1.92 \%$. 南亚热带常绿阔叶林样点 全部重建为其他生物群区类型，大部分误判为寒温带 常绿针叶林(76.56\%).

\section{3 古植被重建}

上述两种方法的重建结果与实际植被对比，显示 随机森林模型重建青藏高原及其周边的现代植被更为 准确性. 因此将随机森林模型用于青藏高原51个化石 点的化石狍粉数据, 定量重建青藏高原22ka以来的植 被变化. 以 500 年为间隔，总计 45 个时段的植被分布变 化详见网络版附录B的附图1.22ka以来可分为五个主 要的植被变化阶段(图5).

阶段 I (22 17ka BP). 青藏高原广布荒漠植被. 该 阶段11个时段中，高原西、中、北部几乎所有化石点 都是温带半灌木-灌木荒漠和暖温带灌木-半灌木荒漠. 东缘和东南缘样点出现亚热带山地寒温性针叶林和中 亚热带常绿阔叶林. 在18.5 17ka BP, 东部个别样点出 现高寒草原和高寒灌丛-高寒草甸.

阶段 II (16.5 12ka BP). 温带半灌木-灌木荒漠和 暖温带灌木-半灌木荒漠分布范围逐渐退到高原北部, 中亚热带常绿阔叶林仍主要分布于东缘和东南缘. 高 寒草原广布于高原中部和东部，并逐渐形成一条高寒 草原带. 高寒灌丛-高寒草甸主要局限在高原东南部 地区.

阶段III(11.5 8ka BP). 温带半灌木-灌木荒漠和暖 温带灌木-半灌木荒漠主要分布在青藏高原北部和西
部, 偶尔出现于中部和东部个别样点. 中亚热带常绿阔 叶林仍分布于高原东缘和东南缘地区，偶尔扩张到高 原中部样点. 在高原东部至东南部逐渐形成一条高寒 灌丛-高寒草甸带, 高寒草原分布范围相应缩小.

阶段 IV (7.5 6ka BP). 温带半灌木-灌木荒漠和暖 温带灌木-半灌木荒漠局限于高原北部和西部. 亚热带 山地寒温性针叶林和中亚热带常绿阔叶林向北扩张, 高寒灌丛-高寒草甸分布范围缩小.

阶段 V (5.5 0ka BP). 温带半灌木-灌木荒漠和暖 温带灌木-半灌木荒漠继续占据高原北部和西部. 高寒 草原占据高原中部, 高寒灌丛-高寒草甸主要分布于东 部和南部. 亚热带山地寒温性针叶林和中亚热带常绿 阔叶林主要分布于高原东南缘，个别时段向北扩张， 如4和1.5ka BP(网络版附图1).

\section{4 讨论}

\section{1 随机森林算法重建现代植被的可靠性}

随机森林算法重建现代狍粉样点的植被时, 重建 结果与样点实际植被有较高的一致性(图2, 表1), 但对 不同植被类型的重建准确率存在差异.

随机森林模型对草甸和荒漠样点的植被重建较为 准确, 包括高寒草甸、高寒灌丛-高寒草甸、暖温带灌 木-半灌木荒漠、温带半灌木-灌木荒漠(表1). 森林植 被类型中，中亚热带常绿阔叶林和亚热带山地寒温性 针叶林样点具有较高的预测准确率. 草原植被中, 只 有温带南部草原样点的预测准确率较高.

除上述两个森林类型外，研究区其余森林类型的 样点常被随机森林模型误判为中亚热带常绿阔叶林 (表1), 原因可能在于不同森林样点的狍粉组合都以 $A l-$ nus、Betula、Pinus、Quercus等乔木类群占优势. 也 有一些森林样点被误判为开阔植被类型，如不少北亚 热带常绿-落叶阔叶混交林样点被划归高寒灌从-高寒 草甸植被, 可能由于北亚热带常绿-落叶阔叶混交林地 带与高寒灌从-高寒草甸地带相邻(图1), 处于森林地带 边缘的样点容易受周边草甸植被狍粉传播的影响, 反 映植被交错带的狍粉特征. 以此类推，暖温带南部落 叶栋林样点常被重建为高寒灌从一高寒草甸和温带南 部草原。

随机森林模型对青藏高原内部高寒草原和温性草 原样点的重建准确率均不高(表1), 大多误判为温带南 

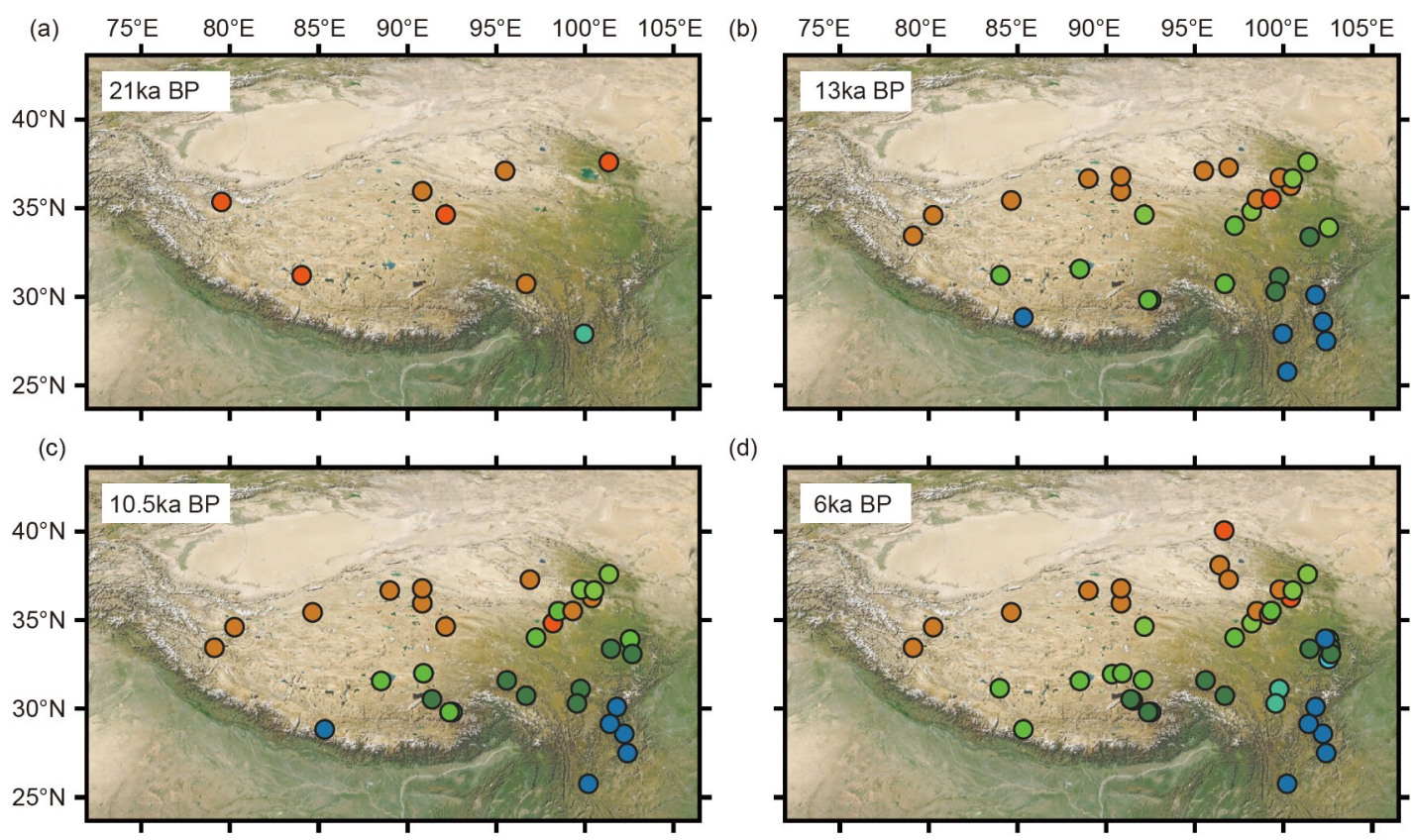

(d)
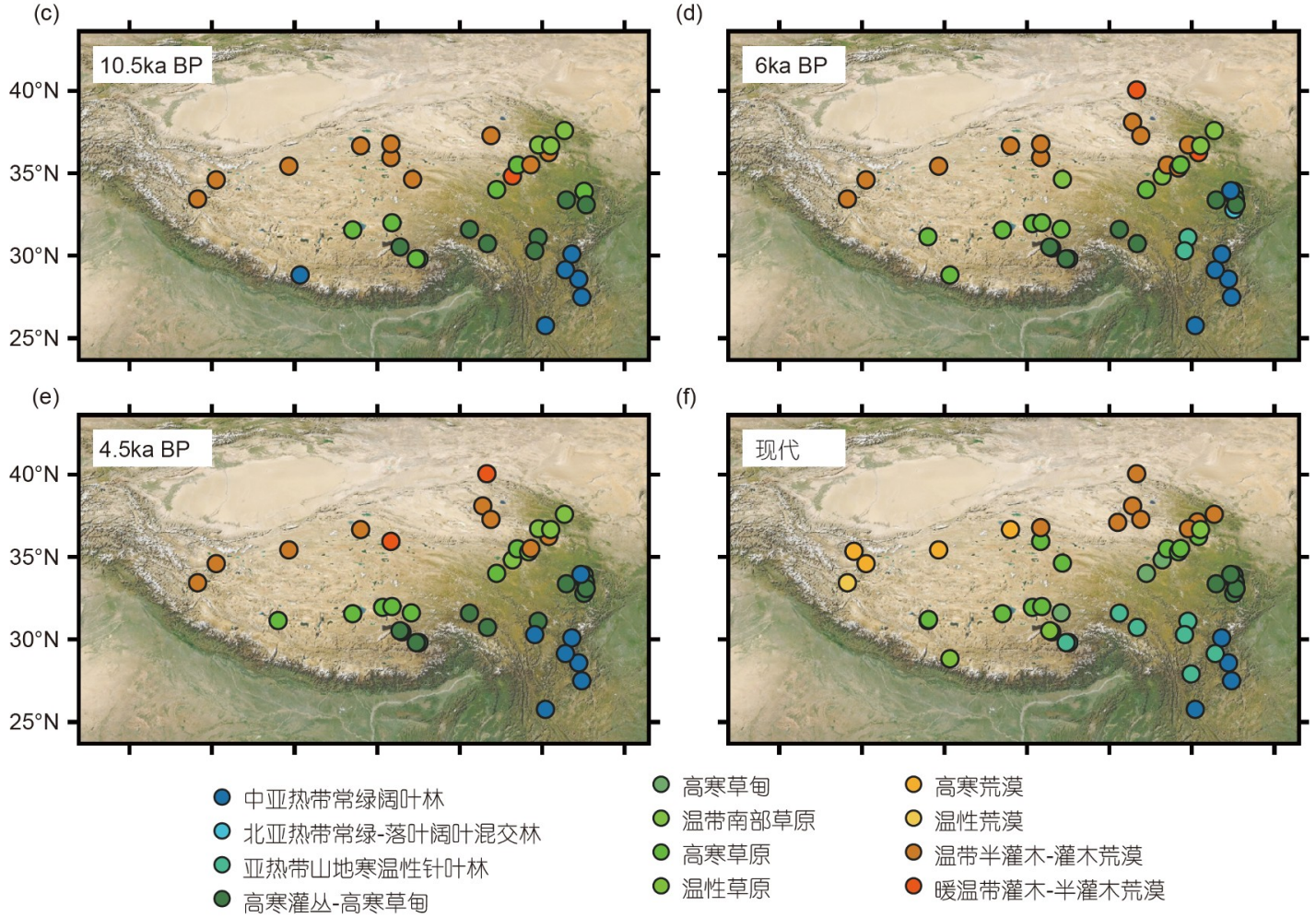

图 5 利用随机森林模型重建的青藏高原 $22 \mathrm{ka}$ 以来五个主要变化阶段的典型植被格局((a) (e), 阶段 I V V), 以及化石点现代 植被分布(f)

部草原、高寒草甸、温带半灌木-灌木荒漠，原因可能 是这些植被类型的狍粉组合中相似类群较多, 如Artemisia、Amaranthaceae/Chenopodiaceae等. 此外，不少 高寒草原和温性草原样点被误判为中亚热带常绿榈叶 林，这可能是受高原东部和东南部亚热带森林远距离 传播而来的乔木花粉影响.

生物群区化法基于同一套现代孢粉数据重建现代 植被的准确率不及随机森林模型(表2)。温带草原和温 带荒漠样点重建准确率较高. 高寒草原和高寒草甸样 点常被误判为其他非森林生物群区. 森林样点中, 热 带季节雨林样点的重建准确率相对较高, 而重建错误
的样点常划归其他森林类型. 北亚热带混交林、暖温 带混交林和温带混交林样点中均至少有一半被重建成 非森林植被. 寒温带常绿针叶林样点被重建成五种生 物群区. 南亚热带常绿阔叶林样点均重建错误，不过 大多被误判为其他森林类型.

生物群区划分方案与植被区划之间的差异可能影 响了本文利用生物群区化法在青藏高原及其周边地区 重建植被的可靠性，例如高寒灌从和高寒草甸是青藏 高原东部的地带性植被，但在本文采用的生物群区划 分方案中二者合并为高寒草甸(Sun等，2020). 不过, Sun等(2020)采用同一套生物群区划分方案利用生物 
群区化法重建中国现代植被分布时，结果显示重建结 果与实际生物群区具有较高的一致性( $80 \%)$. 可能Sun 等(2020)的生物群区划分方案更适合大陆、全球等较 大尺度的植被重建.

由于随机森林模型和生物群区化法的植被类型划 分不一致, 二者重建结果无法直接对比. 因此将二者植 被类型根据生物气候上的相似性归并为更宽泛的 mega-biome(归并方案详见网络版附录B中附表B4), 以 便对比. 因生物气候学特征相似而具有相似孢粉组合 特征的植被类型合并之后，随机森林模型和生物群区 化法的重建结果与实际植被对比时，准确率均有所提 高, 分别升至 $82.57 \%$ 和 $43.01 \%$.

基于孢粉数据利用随机森林模型重建的现代样点 植被清晰地反映了植被的地带性分布(图6). 热带森林 分布于研究区最南端, 亚热带森林处于青藏高原周边 东部至东南部，温带森林少量分布于研究区东部的温 带地区，寒温性针叶林分布于高原东南部，高寒草甸/ 灌丛占据高原东部，温带/高寒荒漠占据研究区北部， 温带/高寒草原散布于高原中部至研究区东北地区.

生物群区化法对现代狍粉数据的重建结果反映出 与随机森林模型结果类似的植被分布(图6). 不同的森 林类型占据高原周边东部至东南地区，高寒草甸/灌丛 主要分布在高原东部, 温带/高寒草原广布于整个青藏 高原及研究区东北部温带地区，温带/高寒荒漠同样占 据研究区北部.

青藏高原的中部至西部的一些高寒草原、高寒荒 漠样点, 用两种方法均重建为森林植被(图6). 这些误 差可能来源于高原周边森林远距离传播的乔木花粉影 响, 而且花粉远距离传播的影响在植被覆盖度较低的 青藏高原内部尤为显著(Cour等, 1999).

总之，随机森林模型有潜力用于重建青藏高原过 去的植被变化. 而生物群区化法采用已有的生物群区 和植物功能型划分方案时，在研究区重建植被的准确 性有待提高.

\section{2 两种植被定量重建方法的优缺点}

随机森林算法最近才引入到基于孢粉数据定量重 建古植被的研究中(Sobol和Finkelstein, 2018; Sobol等, 2019). 而生物群区化法是近二十年来狍粉学研究中定 量重建古植被的常用方法(Prentice和Jolly, 2000; Pickett等, 2004; Marchant等, 2009), 在对中国现代和过去
植被的重建中已显示出较高可靠性(Yu等, 2000; Chen 等, 2010; Ni等, 2010; Ni等, 2014; Tian等, 2018; Sun等, 2020). 两种方法都有各自优缺点及适用范围.

用随机森林算法建立狍粉-植被重建模型有三方 面主要优点(Sobol等, 2019): (1) 基于现代孢粉组合及 其相应植被信息分析狍粉-植被关系, 避免主观划分植 物功能型和生物群区; (2) 所有孢粉数据均用于分析, 减少信息丢失; (3) 模型建立过程中已包含统计检验.

作为以数据为基础的方法，随机森林算法的可靠 性主要依赖训练集的质量. 孢粉鉴定的可靠性是狍粉 数据集质量的重要方面. 由于本文现代狍粉数据集来 自过去多年积累的现代狍粉数据，不同样点的狍粉鉴 定精度存在差异. 在整理狍粉类群时将分类等级较低 的类群合并为较高等级的类群(科和属), 以保持一致 性，但也增加了将生态适应性不同的类群合并为同一 类群的风险.

影响狍粉-植被关系的因素也会增加随机森林模 型的不确定性, 如花粉远距离传播造成的误差, 不同植 物花粉产量的差别, 同一植被类型内部狍粉组合的差 异, 不同沉积物类型狍粉组合的差异等. 另外, 随机森 林算法从狍粉-植被数据中识别出数据的关系, 可能不 具有生态意义(Sobol等, 2019).

随机森林算法本身也有一些弱点. 随机森林模型 无法重建不包含在训练集中的植被类型，例如青藏高 原的高寒荒漠和温性荒漠包含的现代样点数量不足 15 个, 未包含在训练集中, 因此随机森林模型无法重建这 两种植被类型. 而且, 随机森林模型对样本量较低的植 被类型的预测准确率通常较低. 7种具有较高预测准确 率的植被类型所包含的现代样点数量占整个现代孢粉 数据集的 $81 \%$ (表 1$)$, 而其余 6 种植被类型的样点数量仅 占 $19 \%$, 预测准确率也较低. 可见, 样本量较低时可能 无法提供足够的代表性.

生物群区化法的优点是依循生态学规律评估孢粉 组合与生物群区的关系. 该方法根据植物类群的生理 生态学和生物气候学特征划分植物功能型 $(\mathrm{Ni}$ 等, 2010), 依据生物地理学规律定义生物群区，使用合乎 逻辑的公式计算生物群区的相似性得分(Prentice等, 1996). 生物群区化法的可靠性有赖于综合狍粉学和生 态学视角, 建立合理的生物群区和植物功能型划分方 案. 另外，生物群区化法不需要先行利用训练集建立 孢粉-生物群区关系, 即可直接用于重建古植被. 

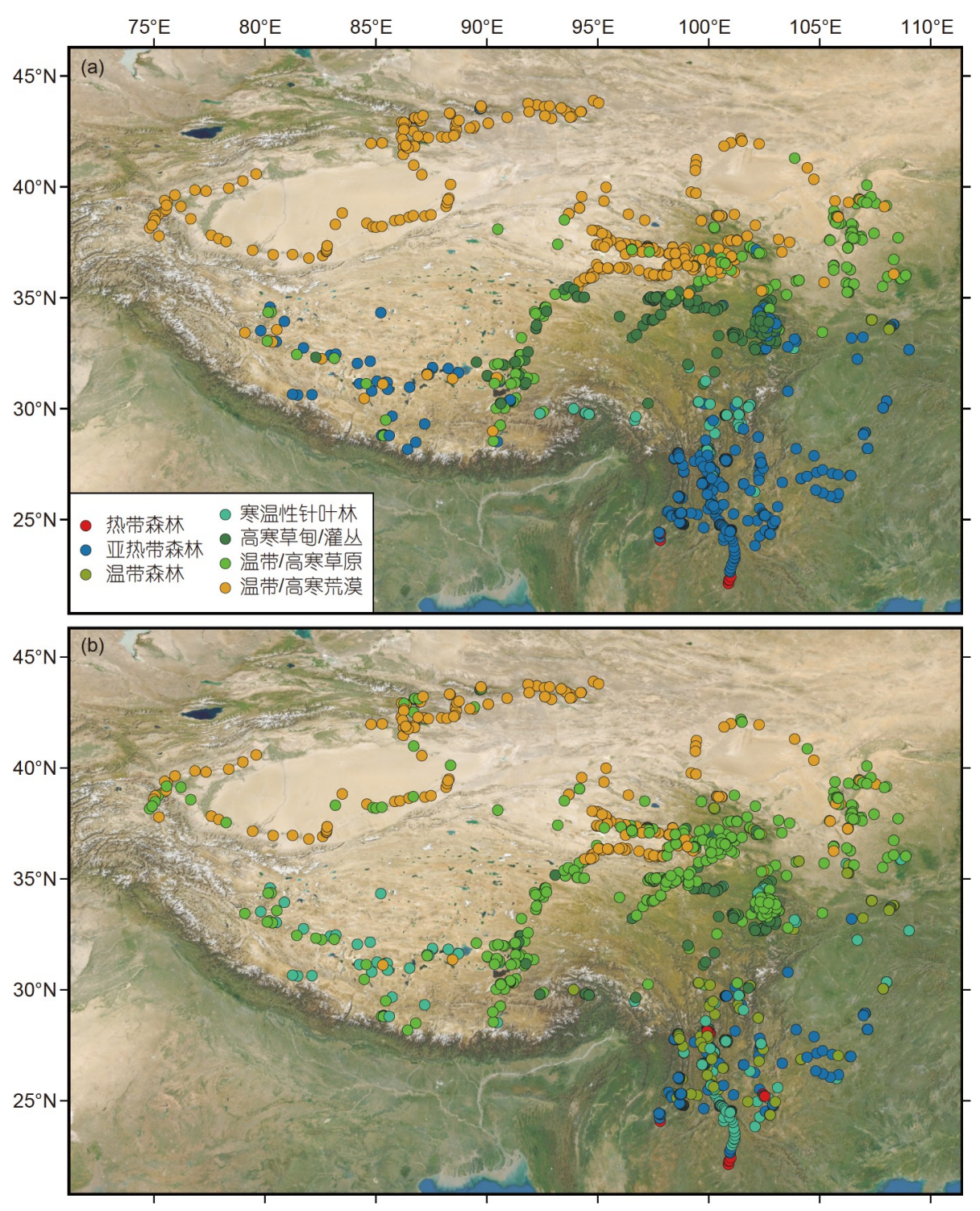

图 6 基于现代狍粉数据利用随机森林模型(a)和生物群区化法(b)重建的mega-biome对比

生物群区化法也有三方面的弱点(Sobol等, 2019). 首先，划分植物功能型和生物群区时多少引入了主观 判断. 其次, 生物群区化法常需人为调节植物功能型 和生物群区划分方案，可能过度拟合狍粉-生物群区的 关系. 最后, 一套植物功能型和生物群区划分方案通常 只适用于特定尺度的植被重建. 例如，本文采用的Sun 等(2020)方案在重建中国范围的植被分布时显示出较 高可靠性，但在本文研究区重建现代植被的准确性不 高. 原因在于这套植物功能型和生物群区划分方案是 依照中国全境的植被格局设计的，可能无法全面地反
映青藏高原的区域植被特征.

在未来研究中, 随机森林模型的可靠性可以从以 下三个方面进行提升：(1) 在现代样点数量不足的植 被地带(高寒荒漠和温性荒漠等)开展新的现代孢粉 调查, 提高现代狍粉数据对这些植被类型的代表性; (2) 开展湖泊沉积物的现代狍粉研究, 以此为湖泊钻 孔的孢粉组合补充更合适的现代类比, 提高孢粉数据 来源的一致性; (3) 使用ERV模型方法(Extended Rvalue model, Sugita, 2007a, 2007b; Bunting和Middleton, 2009)校正孢粉与植被之间的数量关系，减少 
不同狍粉类群代表性和传播能力差异的影响. 对于生 物群区化法, 可以依据青藏高原的区域植被特征调整 植物功能型和生物群区划分方案, 提高其可靠性和适 用性.

\section{3 青藏高原末次冰盛期以来的植被变化}

将新建立的随机森林模型用于青藏高原51个化石 点的狍粉组合, 重建 $22 \mathrm{ka}$ 以来青藏高原植被的时空格 局变化(图5, 网络版附图1). 化石点覆盖了青藏高原不 同的植被地带，但各化石点狍粉序列跨越的时代各不 相同，因此 45 个研究时段上化石点数量不同，某些时 段部分地区缺乏化石点覆盖. 古植被重建结果显示, 从末次冰盛期至今青藏高原的植被格局变化大致与全 球气候和东亚季风的变化趋势一致.

在22 17ka BP(阶段 I ), 荒漠植被占据青藏高原 大部分地区，对应末次冰盛期冷干的气候条件(Shakun 和Carlson, 2010; Clark等, 2012). 亚热带森林分布于高 原东缘和东南缘低海拔地区. 在18.5 17ka BP期间, 草 甸和草原植被开始在高原东部扩张，但尚未成为地带 性植被.

在16.5 12ka BP期间(阶段 II ), 草原植被在高原东 部和中部显著扩张, 逐渐发展成为一条草原带. 高原从 南到北形成亚热带森林、草原、荒漠的分布格局．相 比上一阶段，草甸植被在高原东部占更重要的地位. 该阶段植被变化对应末次冰消期的环境变化(Clark等, 2012; Shi等, 2021). 16.5 13ka BP草原扩张、荒漠向北 退缩; 而13ka BP之后, 荒漠带有向南扩张的趋势, 可能 体现新仙女木事件的影响.

早全新世时(阶段III, 11.5 8ka BP), 草甸植被占据 了青藏高原东部和东南部, 逐渐成为地带性植被. 荒漠 植被主要局限于北部和西部, 而森林植被向北扩张. 逐 渐形成从东南到西北依次分布森林-草甸-草原-荒漠的 格局, 类似现今青藏高原的植被地带性分布. 植被变化 与早全新世全球气候变暖(Marcott等，2013)、亚洲季 风增强(Dykoski等，2005)的趋势一致。不过，在 9.5 8 kaBP期间，荒漠植被扩张到青藏高原中部，可能 体现了 8.2ka冷事件等(Alley等, 1997; Bond等, 1997)千 年尺度气候波动的影响.

青藏高原植被在阶段 IV (7.5 6ka BP) 的分布体现 了适宜期特征，对应东亚季风区的中全新世适宜期 (Chen等, 2019; Zhang等, 2021). 这一阶段亚热带森林
扩张到整个研究时段的最北端，而荒漠局限于研究区 北部和西部.

过去5.5ka(阶段 V)亚热带森林向南退缩，草甸分 布区南移. 草原植被逐渐占据现今的青藏高原的高寒 草原区域，间或入侵现今的高寒草甸区域. 中-晚全新 世青藏高原的植被变化对应气候适宜期之后相对凉干 的气候(Marcott等, 2013; Chen等, 2020).

值得注意的是，青藏高原南部腹地一些样点常重 建为亚热带森林植被，应为重建有误，造成误差的原 因可能来自两个方面：一方面，高原内部的样点容易 受远距离传播而来的乔木花粉影响，尤其是高原东南 的山地针叶林中针叶树的具气囊花粉传播能力强，对 高原内部样点有很大影响; 另一方面，随机森林模型 对高原腹地高寒草原和温性草原样点的预测误差较大 (表1).

大体上，荒漠植被在末次冰盛期时占据青藏高原 大部分地区，之后其分布区逐渐北移，主要分布在高 原北部和西部．草原植被从约 $15 \mathrm{ka} \mathrm{BP}$ 开始占据重要 地位，而草甸向高原东部和东南部的扩张主要发生在 全新世. 亚热带森林在整个研究时段始终在高原东缘 和东南缘占主导，并在早、中全新世向北扩张。青藏 高原东部和南部植被的变化最剧烈, 森林、草甸、草 原、荒漠四种植被不断更替. 不同时段植被对气候变 化的响应也存在差异，例如，荒漠在相对冷干的末次 冰盛期、两次仙女木事件等时期向东、南扩张，但是 在中全新世适宜期之后气候相对恶化时则局限于高原 北部和西部。

利用随机森林算法开展的古植被定量重建展示了 青藏高原末次冰盛期以来连续的植被变化过程. 未来, 通过对比古植被重建结果与模型模拟结果或者基于孢 粉数据定量重建的古气候变化数据, 可以为研究高寒 植被对气候变化的响应提供重要参考. 重建的古植被 格局变化较好地对应了全球气候变化趋势，从侧面反 映随机森林算法重建古植被的可靠性. 可见，该方法 有潜力用于其他地区的古植被定量重建.

\section{5 结论}

由于缺少合适的方法，青藏高原尚缺乏末次冰盛 期以来可靠的植被定量重建，限制了对高寒植被响应 气候变化过程的理解，也阻碍了模型模拟与化石记录 
对比揭示古植被变化机制的深入研究. 本文尝试采用 有监督机器学习方法重建青藏高原古植被变化. 基于 现代孢粉组合用随机森林算法建立狍粉-植被重建模 型，用该模型重建青藏高原及其周边地区现代孢粉组 合的现代植被时显示出较高的准确性. 与生物群区化 法相比，随机森林算法在青藏高原地区预测现代植被 的准确性更高, 不过两种方法也各有优缺点. 总之, 随 机森林算法是基于化石狍粉记录重建青藏高原植被的 可靠方法.

基于 51 个样点的化石孢粉组合，利用新建立的随 机森林模型，定量重建青藏高原2.2万年以来的植被变 化, 形成不同时段的青藏高原植被分布图, 结果显示末 次冰盛期以来青藏高原植被格局变化可以分为五个主 要阶段, 这些植被格局变化很好地对应了末次冰盛期 以来的全球气候变化和亚洲季风演变的趋势. 本研究 是在中国利用机器学习方法定量重建古植被的首次尝 试. 随机森林算法在重建青藏高原古植被时显示出较 高的可靠性，按照与本文相似的流程，该方法极有潜 力用于中国其他地区的古植被定量重建. 甚至对流程 进行一定的调整后，有望用于古气候定量重建. 本文 重建的青藏高原古植被数据, 可以在未来研究中为模 型模拟提供证据, 增进对高寒植被变化机制的理解.

致谢感谢中山大学郑卓教授和中国科学院南京地理与 湖泊研究所肖霞云研究员分享现代狍粉数据, 感谢河北 地质大学梁琛博士协助分析数据, 感谢中国科学院庐山 植物园张志勇博士在生物群区化法方面的有益讨论.

\section{参考文献}

唐领余, 李春海. 2001. 青藏高原全新世植被的时空分布. 冰川冻土, 23: $367-374$

唐领余, 沈才明, 吕厚远, 李春海, 马庆峰. 2021. 青藏高原第四纪胞

粉研究五十年. 中国科学: 地球科学, 51: 2015-2034

吴征镒. 1980. 中国植被. 北京: 科学出版社

秦锋. 2021. 青藏高原草原带和荒漠带湖泊表层沉积物现代花粉研

究. 中国科学: 地球科学, 51: 437-452

张新时. 1978. 西藏植被的高原地带性. 植物学报, 20: 140-149

张新时．2007．中国植被及其地理格局-中华人民共和国植被图

(1:1000000)说明书. 北京: 地质出版社

张镱锂, 李炳元, 郑度. 2014. 青藏高原范围界线与面积地理信息系 统数据. 地理学报, 69: 65-68

郑度, 张荣祖, 杨勤业. 1979. 试论青藏高原的自然地带. 地理学报,
34: $1-11$

Alley R B, Mayewski P A, Sowers T, Stuiver M, Taylor K C, Clark P U. 1997. Holocene climatic instability: A prominent, widespread event 8200 yr ago. Geology, 25: 483-486

An Z S, Kutzbach J E, Prell W L, Porter S C. 2001. Evolution of Asian monsoons and phased uplift of the Himalaya-Tibetan plateau since Late Miocene times. Nature, 411: 62-66

An Z S, Wu G X, Li J P, Sun Y B, Liu Y, Zhou W J, Cai Y J, Duan A M, Li L, Mao J Y, Cheng H, Shi Z G, Tan L C, Yan H, Ao H, Chang H, Feng J. 2015. Global monsoon dynamics and climate change. Annu Rev Earth Planet Sci, 43: 29-77

Blaauw M, Christen J A. 2011. Flexible paleoclimate age-depth models using an autoregressive gamma process. Bayesian Anal, 6: 457-474

Blaauw M, Christen J A. 2019. rbacon: Age-Depth Modelling using Bayesian Statistics

Bond G, Showers W, Cheseby M, Lotti R, Almasi P, Demenocal P, Priore P, Cullen H, Hajdas I, Bonani G. 1997. A pervasive millennial-scale cycle in North Atlantic Holocene and Glacial climates. Science, 278: 1257-1266

Breiman L, Friedman J H, Olshen R A, Stone C J. 1984. Classification and Regression Trees. Monterey: Wadsworth and Brooks/Cole

Breiman L. 2001. Random Forests. Mach Learn, 45: 5-32

Bunting M J, Middleton R. 2009. Equifinality and uncertainty in the interpretation of pollen data: The Multiple Scenario Approach to reconstruction of past vegetation mosaics. Holocene, 19: 799-803

Cao X Y, Herzschuh U, Telford R J, Ni J. 2014. A modern pollenclimate dataset from China and Mongolia: Assessing its potential for climate reconstruction. Rev Palaeobot Palynol, 211: 87-96

Cao X Y, Ni J, Herzschuh U, Wang Y B, Zhao Y. 2013. A late Quaternary pollen dataset from eastern continental Asia for vegetation and climate reconstructions: Set up and evaluation. Rev Palaeobot Palynol, 194: 21-37

Chen F H, Chen J H, Huang W, Chen S Q, Huang X Z, Jin L Y, Jia J, Zhang X J, An C B, Zhang J W, Zhao Y, Yu Z C, Zhang R H, Liu J B, Zhou A F, Feng S. 2019. Westerlies Asia and monsoonal Asia: Spatiotemporal differences in climate change and possible mechanisms on decadal to sub-orbital timescales. Earth-Sci Rev, 192: 337354

Chen F H, Zhang J F, Liu J B, Cao X Y, Hou J Z, Zhu L P, Xu X K, Liu X J, Wang M D, Wu D, Huang L X, Zeng T, Zhang S, Huang W, Zhang X, Yang K. 2020. Climate change, vegetation history, and landscape responses on the Tibetan Plateau during the Holocene: A comprehensive review. Quat Sci Rev, 243: 106444

Chen Y, Ni J, Herzschuh U. 2010. Quantifying modern biomes based on surface pollen data in China. Glob Planet Change, 74: 114-131 Clark P U, Shakun J D, Baker P A, Bartlein P J, Brewer S, Brook E, 
Carlson A E, Cheng H, Kaufman D S, Liu Z, Marchitto T M, Mix A C, Morrill C, Otto-Bliesner B L, Pahnke K, Russell J M, Whitlock C, Adkins J F, Blois J L, Clark J, Colman S M, Curry W B, Flower B P, He F, Johnson T C, Lynch-Stieglitz J, Markgraf V, McManus J, Mitrovica J X, Moreno P I, Williams J W. 2012. Global climate evolution during the last deglaciation. Proc Natl Acad Sci USA, 109: E1134-E1142

Cour P, Zheng Z, Duzer D, Calleja M, Yao Z. 1999. Vegetational and climatic significance of modern pollen rain in northwestern Tibet. Rev Palaeobot Palynol, 104: 183-204

Cutler D R, Edwards Jr T C, Beard K H, Cutler A, Hess K T, Gibson J, Lawler J J. 2007. Random forests for classification in ecology. Ecology, 88: 2783-2792

Dallmeyer A, Claussen M, Herzschuh U, Fischer N. 2011. Holocene vegetation and biomass changes on the Tibetan Plateau-A modelpollen data comparison. Clim Past, 7: 881-901

Dykoski C A, Edwards R L, Cheng H, Yuan D X, Cai Y J, Zhang M L, Lin Y S, Qing J M, An Z S, Revenaugh J. 2005. A high-resolution, absolute-dated Holocene and deglacial Asian monsoon record from Dongge Cave, China. Earth Planet Sci Lett, 233: 71-86

Fall P L. 1992. Pollen accumulation in a montane region of Colorado, USA: A comparison of moss polsters, atmospheric traps, and natural basins. Rev Palaeobot Palynol, 72: 169-197

Felde V A, Peglar S M, Bjune A E, Grytnes J A, Birks H J B. 2014. The relationship between vegetation composition, vegetation zones and modern pollen assemblages in Setesdal, southern Norway. Holocene, 24: 985-1001

Guiot J, Goeury C. 1996. PPPBase, a software for statistical analysis of paleoecological and paleoclimatological data. Dendrochronol, 14: 295-300

Herzschuh U, Borkowski J, Schewe J, Mischke S, Tian F. 2014 Moisture-advection feedback supports strong early-to-mid Holocene monsoon climate on the eastern Tibetan Plateau as inferred from a pollen-based reconstruction. Palaeogeogr Palaeoclimatol Palaeoecol, 402: 44-54

Herzschuh U, Kramer A, Mischke S, Zhang C J. 2009. Quantitative climate and vegetation trends since the late glacial on the northeastern Tibetan Plateau deduced from Koucha Lake pollen spectra. Quat Res, 71: 162-171

Herzschuh U, Winter K, Wunnemann B, Li S J. 2006. A general cooling trend on the central Tibetan Plateau throughout the Holocene recorded by the Lake Zigetang pollen spectra. Quat Int, 154-155: $113-121$

Li K, Liao M N, Ni J, Liu X Q, Wang Y B. 2019. Treeline composition and biodiversity change on the southeastern Tibetan Plateau during the past millennium, inferred from a high-resolution alpine pollen record. Quat Sci Rev, 206: 44-55

Liaw A, Wiener M. 2002. Classification and regression by random forest. R News, 2: 18-22

Lisitsyna O V, Hicks S, Huusko A. 2012. Do moss samples, pollen traps and modern lake sediments all collect pollen in the same way? A comparison from the forest limit area of northernmost Europe. Veget Hist Archaeobot, 21: 187-199

Marchant R, Cleef A, Harrison S P, Hooghiemstra H, Markgraf V, van Boxel J, Ager T, Almeida L, Anderson R, Baied C, Behling H, Berrio J C, Burbridge R, Björck S, Byrne R, Bush M, Duivenvoorden J, Flenley J, De Oliveira P, van Geel B, Graf K, Gosling W D, Harbele S, van der Hammen T, Hansen B, Horn S, Kuhry P, Ledru M P, Mayle F, Leyden B, Lozano-García S, Melief A M, Moreno P, Moar N T, Prieto A, van Reenen G, SalgadoLabouriau M, Schäbitz F, Schreve-Brinkman E J, Wille M. 2009. Pollen-based biome reconstructions for Latin America at 0, 6000 and 18000 radiocarbon years ago. Clim Past, 5: 725-767

Marcott S A, Shakun J D, Clark P U, Mix A C. 2013. A reconstruction of regional and global temperature for the past 11,300 years. Science, 339: 1198-1201

Molnar P, Boos W R, Battisti D S. 2010. Orographic controls on climate and paleoclimate of Asia: Thermal and mechanical roles for the Tibetan Plateau. Annu Rev Earth Planet Sci, 38: 77-102

Ni J, Cao X Y, Jeltsch F, Herzschuh U. 2014. Biome distribution over the last 22,000 yr in China. Palaeogeogr Palaeoclimatol Palaeoecol, 409: 33-47

Ni J, Yu G, Harrison S P, Prentice I C. 2010. Palaeovegetation in China during the late Quaternary: Biome reconstructions based on a global scheme of plant functional types. Palaeogeogr Palaeoclimatol Palaeoecol, 289: 44-61

Pickett E J, Harrison S P, Hope G, Harle K, Dodson J R, Peter Kershaw A, Colin Prentice I, Backhouse J, Colhoun E A, D’Costa D, Flenley J, Grindrod J, Haberle S, Hassell C, Kenyon C, Macphail M, Martin H, Martin A H, McKenzie M, Newsome J C, Penny D, Powell J, Ian Raine J, Southern W, Stevenson J, Sutra J P, Thomas I, Kaars S, Ward J. 2004. Pollen-based reconstructions of biome distributions for Australia, Southeast Asia and the Pacific (SEAPAC region) at 0 , 6000 and $18,000{ }^{14} \mathrm{C}$ yr BP. J Biogeogr, 31: 1381-1444

Prentice C, Guiot J, Huntley B, Jolly D, Cheddadi R. 1996. Reconstructing biomes from palaeoecological data: A general method and its application to European pollen data at 0 and 6 ka. Clim Dyn, 12: 185-194

Prentice I C, Jolly D. 2000. Mid-Holocene and glacial-maximum vegetation geography of the northern continents and Africa. J Biogeogr, 27: 507-519

Prentice I C, Webb III T. 1998. BIOME 6000: Reconstructing global 
mid-Holocene vegetation patterns from palaeoecological records. J Biogeogr, 25: 997-1005

R Core Team. 2018. R: A language and environment for statistical computing. Vienna, Austria: R Foundation for Statistical Computing

Shakun J D, Carlson A E. 2010. A global perspective on Last Glacial Maximum to Holocene climate change. Quat Sci Rev, 29: 18011816

Shen C M, Liu K B, Tang L Y, Overpeck J T. 2006. Quantitative relationships between modern pollen rain and climate in the Tibetan Plateau. Rev Palaeobot Palynol, 140: 61-77

Shi F, Lu H Y, Guo Z T, Yin Q Z, Wu H B, Xu C X, Zhang E L, Shi J F, Cheng J, Xiao X Y, Zhao C. 2021. The position of the Current Warm Period in the context of the past 22,000 years of summer climate in China. Geophys Res Lett, 48: e91940

Shi W, Jiang H C, Mao X, Xu H Y. 2020. Pollen record of climate change during the last deglaciation from the eastern Tibetan Plateau. PLoS ONE, 15: e0232803

Sobol M K, Finkelstein S A. 2018. Predictive pollen-based biome modeling using machine learning. PLoS ONE, 13: e0202214

Sobol M K, Scott L, Finkelstein S A. 2019. Reconstructing past biomes states using machine learning and modern pollen assemblages: A case study from Southern Africa. Quat Sci Rev, 212: 1-17

Song M H, Zhou C P, Ouyang H. 2005. Simulated distribution of vegetation types in response to climate change on the Tibetan Plateau. J Vegetation Sci, 16: 341-350

Sugita S. 2007a. Theory of quantitative reconstruction of vegetation I: Pollen from large sites REVEALS regional vegetation composition. Holocene, 17: 229-241

Sugita S. 2007b. Theory of quantitative reconstruction of vegetation II: All you need is LOVE. Holocene, 17: 243-257

Sun A Z, Luo Y L, Wu H B, Chen X D, Guo Z T. 2020. An updated biomization scheme and vegetation reconstruction based on a synthesis of modern and mid-Holocene pollen data in China. Glob Planet Change, 192: 103178

Tian F, Cao X Y, Dallmeyer A, Lohmann G, Zhang X, Ni J, Andreev A, Anderson P M, Lozhkin A V, Bezrukova E, Rudaya N, Xu Q H, Herzschuh U. 2018. Biome changes and their inferred climatic drivers in northern and eastern continental Asia at selected times since 40 cal ka bp. Veget Hist Archaeobot, 27: 365-379
Wilmshurt J M, McGlone M S. 2005. Origin of pollen and spores in surface lake sediments: Comparison of modern palynomorph assemblages in moss cushions, surface soils and surface lake sediments. Rev Palaeobot Palynol, 136: 1-15

Yu G, Chen X, Ni J, Cheddadi R, Guiot J, Han H, Harrison S P, Huang C, Ke M, Kong Z C, Li S, Li W Y, Liew P, Liu G, Liu J, Liu Q, Liu K B, Prentice I C, Qui W, Ren G, Song C, Sugita S, Sun X J, Tang L Y, van C E, Xia Y, Xu Q H, Yan S, Yang X, Zhao J, Zheng Z. 2000. Palaeovegetation of China: A pollen data-based synthesis for the mid-Holocene and last glacial maximum. J Biogeogr, 27: 635-664

Zhang Z P, Liu J B, Chen J, Chen S Q, Shen Z W, Chen J, Liu X K, Wu D, Sheng Y W, Chen F H. 2021. Holocene climatic optimum in the East Asian monsoon region of China defined by climatic stability. Earth-Sci Rev, 212: 103450

Zhao Y, Liang C, Cui Q Y, Qin F, Zheng Z, Xiao X Y, Ma C M, Felde V A, Liu Y L, Li Q, Zhang Z Y, Herzschuh U, Xu Q H, Wei H C, Cai M T, Cao X Y, Guo Z T, Birks H J B. 2021. Temperature reconstructions for the last 1.74-Ma on the eastern Tibetan Plateau based on a novel pollen-based quantitative method. Glob Planet Change, 199: 103433

Zhao Y, Tzedakis P C, Li Q, Qin F, Cui Q, Liang C, Birks H J B, Liu Y L, Zhang Z Z, Ge J Y, Zhao H, Felde V A, Deng C L, Cai M T, Li H, Ren W H, Wei H C, Yang H F, Zhang J W, Yu Z C, Guo Z T. 2020. Evolution of vegetation and climate variability on the Tibetan Plateau over the past 1.74 million years. Sci Adv, 6: eaay6193

Zhao Y, Xu Q H, Huang X Z, Guo X L, Tao S C. 2009. Differences of modern pollen assemblages from lake sediments and surface soils in arid and semi-arid China and their significance for pollen-based quantitative climate reconstruction. Rev Palaeobot Palynol, 156: 519-524

Zhao Y, Yu Z C, Zhao W W. 2011. Holocene vegetation and climate histories in the eastern Tibetan Plateau: Controls by insolationdriven temperature or monsoon-derived precipitation changes? Quat Sci Rev, 30: 1173-1184

Zheng Z, Wei J H, Huang K Y, Xu Q H, Lü H Y, Tarasov P, Luo C X, Beaudouin C, Deng Y, Pan A D, Zheng Y W, Luo Y L, Nakagawa T, Li C H, Yang S X, Peng H H, Cheddadi R. 2014. East Asian pollen database: Modern pollen distribution and its quantitative relationship with vegetation and climate. J Biogeogr, 41: 1819-1832

(责任编委: 吴海斌) 